Nowe kierunki w zarządzaniu przedsiębiorstwem.

ISSN 1899-3192

Procesy i projekty w zarządzaniu zmianami

e-ISSN 2392-0041

\title{
Mirosław Moroz
}

Uniwersytet Ekonomiczny we Wrocławiu

e-mail: miroslaw.moroz@ue.wroc.pl

\section{ZARZĄDZANIE ZMIANĄ W JEDNOOSOBOWEJ DZIALALNOŚCI GOSPODARCZEJ OPERUJĄCEJ W PRZESTRZENI WIRTUALNEJ}

\section{CHANGE MANAGEMENT IN A ONE-MAN COMPANY OPERATING IN THE VIRTUAL SPACE}

DOI: $10.15611 /$ pn.2017.463.05

Streszczenie: Zmienność otoczenia, jak również kreowanie zmian w samym przedsiębiorstwie pociąga za sobą konieczność bezustannego zarządzania zmianami. W artykule podjęto problem badawczy zarządzania zmianami w jednoosobowym przedsiębiorstwie działającym w przestrzeni wirtualnej, a więc środowisku o wysokiej i nieprzewidywalnej dynamice zmian. Celem artykułu jest jakościowa analiza czynników utrudniających i ułatwiających wdrażanie zmian przez przedsiębiorstwo jednoosobowe działające w przestrzeni wirtualnej. Zastosowano dwie metody badawcze: krytyczną analizę dokumentacji oraz metodę wywiadu skategoryzowanego. Wyniki badań wskazują, że prowadzenie biznesu internetowego niesie wyzwania ze względu na percepcję i wdrażanie zmian. $Z$ drugiej jednak strony automatyzacja działalności w oparciu o stosowane oprogramowanie, jak również posiłkowanie się usługami zewnętrznymi pozwala na sprawne wdrażanie zmian nawet $\mathrm{w}$ przedsiębiorstwach jednoosobowych.

Słowa kluczowe: zarządzanie zmianą, przedsiębiorstwo jednoosobowe, elastyczność przedsiębiorstwa, e-commerce, sklep internetowy.

Summary: The volatility of the environment, as well as creating changes in the company, implies the need for continuous change management. The paper raised the research problem of change management in a one-man company operating in the virtual space, so in the environment of high and unpredictable dynamics of change. The aim of the paper is to analyse the factors that positively and negatively affect the ability to take account of changes in the functioning of a one-man undertaking, operating in the virtual space. Two research methods were applied: the critical analysis of documentation and the method of the categorised interview. Findings show that running an Internet business is bringing challenges on account of the perception and implementing changes. However, on the other hand, automate activities based on software applications, as well as using external services allow for the smooth implementation of the changes even in one-band companies.

Keywords: change management, one-man company, business flexibility, e-commerce, e-shop. 


\section{Wstęp}

Prowadzenie przedsiębiorstwa $\mathrm{w}$ aktualnych uwarunkowaniach rynkowych wiąże się z koniecznością uwzględnienia znaczącej zmienności funkcjonowania. Z jednej strony w otoczeniu panuje turbulencja wywołana postępem naukowo-technicznym, globalizacją, deregulacją itd. Również wewnątrz przedsiębiorstwa indukowane są zmiany, przejawiające się np. poprzez wprowadzenie nowych produktów (innowacyjność), zmiany instrumentów konkurowania (strategia konkurencji) czy zmiany modelów biznesowych. W takich uwarunkowaniach jedną z najważniejszych przesłanek sukcesu staje się umiejętność skutecznego zarządzania zmianą, rozumianą w sposób praktyczny jako zdolność do odpowiedniej reakcji/akcji w codziennych procesach zarządzania przedsiębiorstwem.

W przestrzeni wirtualnej funkcjonują przedsiębiorstwa, których łańcuch tworzenia wartości opiera się na dobrach niematerialnych (informacji w zdigitalizowanej formie). Sklepy internetowe, portale, serwisy rezerwacyjne, porównywarki cen i wiele innych są przykładem przedsiębiorstw internetowych. Przestrzeń wirtualna cechuje się jeszcze większym stopniem zmienności, co z kolei uwypukla znaczenie zarządzania zmianami. $\mathrm{Z}$ drugiej jednak strony niematerialny łańcuch tworzenia wartości umożliwia automatyzację działań i w ten sposób kreuje powstawanie przedsiębiorstw jednoosobowych. Ze względu na swą specyfikę - pracę jednej osoby w sferze regulacyjnej i wykonawczej - zarządzanie zmianą w podmiocie jednoosobowym różni się od zarządzania zmianą $\mathrm{W}$ większym przedsiębiorstwie. W literaturze przedmiotu wątek zarządzania podmiotem jednoosobowym właściwie nie występuje. Dlatego też na kanwie wskazanej luki badawczej pojawia się problem badawczy zarządzania zmianami w przedsiębiorstwie jednoosobowym.

Celem artykułu jest jakościowa analiza czynników utrudniających i ułatwiających wdrażanie zmian przez przedsiębiorstwo jednoosobowe, działające w przestrzeni wirtualnej. Aby uwypuklić problematykę zarządzania zmianami, posłużono się studium przypadku sklepu internetowego. Segment sklepów internetowych poddany jest dużej zmienności.

Aby zrealizować tak określony cel, wybrano następujące metody badawcze: analizę dokumentacji oraz wywiad skategoryzowany. Wybór metod badawczych został podyktowany złożoną, jakościową specyfiką zarządzania zmianami.

Struktura artykułu obejmuje prezentację e-biznesu jako środowiska o wysokiej zmienności, wskazanie specyfiki jednoosobowej działalności gospodarczej oraz praktyczne aspekty zarządzania zmianą sklepu internetowego prowadzonego przez jednego właściciela.

Ze względów leksykalnych autor w dalszej części pracy zamiennie stosował będzie pojęcia: „przedsiębiorstwo”, „,firma”, „podmiot” (gospodarczy), „organizacja”. Pozostając w kręgu wątków pojęciowych, autor za zasadne uznaje stosowanie pojęcia „przedsiębiorstwo jednoosobowe”. Faktycznie, w ramach ekonomiki i organizacji przedsiębiorstwa długi czas toczyła się dyskusja, czy przedsiębiorstwo jednoosobowe to już (jeszcze) przedsiębiorstwo. Jednak zgodnie z literaturą przedmiotu przyjmuje się, że tak właśnie jest [Gruszecki 2002, s. 160; Karaś 2003, s. 60]. Podobnie z prawnego i statystycznego punktu widzenia uznaje się firmy jednoosobowe za przedsiębiorstwa. 


\section{Zarządzanie zmianą $\mathbf{w}$ wirtualnej przestrzeni}

Zmiany są immanentnym elementem zarządzania. Pojawiające się zmiany wywołują konieczność dostrojeń w systemie zarządzania przedsiębiorstwem. To z kolei powoduje określone skutki dla strategicznego bądź operacyjnego zarządzania organizacją. W następstwie pojawia się następna fala zmian, która wzbudza kolejne modyfikacje. Oddziaływanie zmiany na system zarządzania ma charakter iteracyjny i wielopoziomowy. Tym samym zarządzanie zmianą jest jednym z podstawowych elementów zarządzania przedsiębiorstwem $\mathrm{i}$ jako takie znajduje się w centrum zainteresowania nauk o zarządzaniu. Zarządzanie zmianą w swej istocie dotyczy wdrażania w życie procesu kreowania zmian, ich realizacji, kierowania zmianami oraz utrzymania ich efektów [Clarke 1997, s. xi; Hayes 2014, s. 2].

Proces zarządzania zmianami uwarunkowany jest rodzajem zmian. Zmiany można klasyfikować według różnych kryteriów: głębokości, zakresu, tempa przemian. Jednak z zarządczego punktu widzenia ważniejsze wydają się inne cechy: źródła zmian oraz charakteru możliwych do podjęcia przez organizację działań. W tabeli 1 przedstawiono rodzaje zmian ze względu na odpowiedź organizacji.

Tabela 1. Charakter zmian a rodzaje działań uruchamianych przez przedsiębiorstwo

\begin{tabular}{|l|l|l|l|l|}
\hline \multicolumn{1}{|c|}{ Rodzaj zmian } & $\begin{array}{c}\text { Charakter } \\
\text { zmienności }\end{array}$ & \multicolumn{1}{|c|}{ Typ działań } & Źródło impulsu & \multicolumn{1}{c|}{ Działania organizacji } \\
\hline Przewidywalne & Zwykły & Antycypacyjne & $\begin{array}{l}\text { Zewnętrzne/ } \\
\text { wewnętrzne }\end{array}$ & $\begin{array}{l}\text { Rutyna (procedury, } \\
\text { plany) }\end{array}$ \\
\hline Nieprzewidywalne & Nieokreślony & Adaptacyjne & Zewnętrzne & Dostosowanie \\
\cline { 3 - 5 } & & Innowacyjne & Wewnętrzne & $\begin{array}{l}\text { Rekonfiguracja, odnowa } \\
\text { strategiczna }\end{array}$ \\
\hline
\end{tabular}

Źródło: [Moroz 2013, s. 22].

Przy standardowym zakresie zmienności, który można przewidzieć, zarządzanie zmianami polegać będzie na przygotowaniu odpowiednich procedur postępowania. W sytuacji nieprzewidzianych zmian w otoczeniu typową reakcją organizacji jest uruchomienie działań dostosowawczych. Z kolei w sytuacji, gdy impuls zmian pochodzi z wewnątrz organizacji, następuje rekonfiguracja zasobów, zmiana modelu biznesowego itd. Tak więc zarządzanie zmianą w praktyce działalności gospodarczej oznacza zdolność do odpowiedniej reakcji/akcji w zależności od charakteru zmian.

Przestrzeń wirtualna stanowi obecnie dynamiczną płaszczyznę prowadzenia biznesu. Poprzez Internet można sprzedawać, kupować, prowadzić komunikację, rezerwować, potwierdzać tożsamość, porównywać ceny produktów itp. Sektor przedsiębiorstw internetowych cały czas dynamicznie rośnie. W tabeli 2 zaprezentowano główne segmenty e-biznesu wraz z przykładowymi typami przedsięwzięć. 
Tabela 2. Segmenty e-biznesu

\begin{tabular}{|c|c|c|}
\hline Segment e-biznesu & Źródło przychodów & Rodzaje przedsięwzięć \\
\hline \multirow{6}{*}{$\begin{array}{l}\text { Serwisy internetowe } \\
\text { i e-usługi }\end{array}$} & \multirow{6}{*}{$\begin{array}{l}\text { Przychody ze sprzedaży reklamy, } \\
\text { abonamentów, treści, płatne funkcje } \\
\text { (także w modelu freemium) }\end{array}$} & Portale \\
\hline & & Serwisy ogłoszeniowe, katalogi firm \\
\hline & & Serwisy społecznościowe \\
\hline & & Serwisy tematyczne (wortale) \\
\hline & & Serwisy wideo \\
\hline & & Porównywarki cenowe \\
\hline \multirow[t]{3}{*}{ E-marketing } & \multirow{3}{*}{$\begin{array}{l}\text { Obsługa kampanii reklamowych, } \\
\text { doradztwo, pozycjonowanie }\end{array}$} & Agencje interaktywne \\
\hline & & Agencje SEO/SEM \\
\hline & & Sieci reklamowe \\
\hline \multirow[t]{3}{*}{ Handel elektroniczny } & \multirow{3}{*}{$\begin{array}{l}\text { Marża ze sprzedaży produktów, } \\
\text { opłaty i prowizje dodatkowe }\end{array}$} & Sklepy internetowe \\
\hline & & Serwisy aukcyjne \\
\hline & & Serwisy zakupów grupowych \\
\hline
\end{tabular}

Źródło: opracowanie własne na podstawie [IDG S.A. 2010].

Przestrzeń wirtualna cechuje się wyższym - w porównaniu z tradycyjnym środowiskiem prowadzenia biznesu - zakresem i tempem zmian. Wynika to z sieciowego charakteru Internetu i jego globalnego zasięgu, pozwalającego na szybkie przenoszenie informacji z jednego krańca świata w drugi. U podstaw większej zmienności biznesu internetowego leżą szybsze pojawianie się nowych technologii (np. video streaking), przemiany kulturowe (społeczne) oraz wyłaniające się na tych podstawach nowe modele biznesowe.

Tabela 3. Poziom zmienności a środowisko prowadzenia biznesu

\begin{tabular}{|l|l|l|}
\hline & \multicolumn{1}{|c|}{ Tradycyjne środowisko biznesu } & \multicolumn{1}{|c|}{ Przestrzeń wirtualna } \\
\hline Cykle gospodarcze & Przewidywalne & Brak reguł \\
\hline Wzrosty i prosperity & Określone (średnio co 7 lat) & Nieregularne, nieprzewidywalne \\
\hline Spadki i recesje & Określone (średnio co 10 miesięcy) & Nieregularne, nieprzewidywalne \\
\hline $\begin{array}{l}\text { Szybkość rozchodzenia } \\
\text { się trendów/mód }\end{array}$ & Umiarkowana & Wysoka \\
\hline Turbulencja & Zdarza się & Występuje permanentnie \\
\hline $\begin{array}{l}\text { Pojawianie się nowych } \\
\text { modeli biznesowych }\end{array}$ & Od czasu do czasu & Non stop \\
\hline $\begin{array}{l}\text { Latwość kopiowania } \\
\text { pomysłu na biznes }\end{array}$ & Średnia & Znaczna \\
\hline
\end{tabular}

Źródło: opracowanie własne na podstawie [Kotler, Caslione 2009, s. 497-504]. 
W tabeli 3 zarysowano różnicę między poziomem zmienności przedsiębiorstw tradycyjnych i internetowych.

Powyższe ustalenia koncentrują uwagę na przesłankach większej zmienności w przestrzeni wirtualnej. Uwzględniają przy tym typowe (średnie) stany poziomu zmienności poszczególnych czynników.

Podstawą tak zarysowanych przesłanek jest obserwacja biznesu internetowego. Dostępne statystyki również potwierdzają olbrzymią dynamikę zmian zachodzących w Internecie. Ze względu na ograniczony rozmiar niniejszego opracowania w tabeli 4 zaprezentowane zostaną dane odnoszące się do częstotliwości korzystania z określonych narzędzi internetowych w ciągu 3 lat (2013-2015).

Tabela 4. Liczba operacji wykonanych przez internautów w ciągu jednej minuty (60 sekund) w 2013, 2014 i 2015 roku

\begin{tabular}{|l|r|r|c|}
\hline \multicolumn{1}{|c|}{ Aktywność } & 2013 & 2014 & 2015 \\
\hline Wysłane e-maile [w milionach] & 182,9 & 196,3 & 205,6 \\
\hline $\begin{array}{l}\text { Liczba wpisów w serwisie społecznościowym } \\
\text { Facebook [w milionach] }\end{array}$ & 2,5 & 2,46 & 3,3 \\
\hline $\begin{array}{l}\text { Liczba wyszukiwań w wyszukiwarce Google } \\
\text { [w milionach] }\end{array}$ & 2,6 & 2,4 & 3,1 \\
\hline $\begin{array}{l}\text { Liczba godzin pobranych materiałów wideo } \\
\text { z serwisu YouTube [w godzinach] }\end{array}$ & 100 & 300 & 400 \\
\hline $\begin{array}{l}\text { Liczba zdjęć pobranych z serwisu Instagram } \\
\text { [w tysiącach] }\end{array}$ & 28 & 42 & 55 \\
\hline
\end{tabular}

Źródło: [Allen 2016].

Za powyższą wysoką dynamiką korzystania z Internetu stoją zmiany kulturowe (zmniejszenie zakresu prywatności, chęć autokreacji,), technologiczne (udostępnienie na szeroka skalę technologii mobilnych) i biznesowe (ograniczenie kosztów korzystania z urządzeń fotograficznych i telefonicznych, dopracowanie modeli biznesowych). Wszystko to razem wzięte generuje wysoki poziom złożoności dla biznesu internetowego.

Zarządzanie zmianą przedsiębiorstw operujących w przestrzeni wirtualnej musi uwzględniać znaczną zmienność tam panującą. Przynajmniej teoretycznie. Praktyka pokazuje bowiem, że wielu zarządzających nie do końca zdaje sobie sprawę z tego wymiaru zarządzania. Według dostępnych statystyk w Polsce w ciągu jednego dnia upadają 2 sklepy internetowe. Jednak na ich miejsce powstaje 5 nowych [Ścibior 2008].

\section{Specyfika przedsiębiorstwa jednoosobowego}

Przedsiębiorstwa jednoosobowe stanowią jedną z najbardziej licznych grup przedsiębiorstw w gospodarce rynkowej. Jako takie w dużej mierze kształtują wypracowaną 
wartość dodaną, eksport, liczbę zatrudnionych. W tym miejscu warto zaznaczyć, że przedsiębiorstwo jednoosobowe rozumiane jest w niniejszym opracowaniu jako firma, w której właściciel jest jednocześnie wykonawcą działań (nie zatrudnia pracowników). Nie chodzi tu więc o występującą w przepisach formę organizacyjno prawną.

Z klasyfikacyjnego punktu widzenia firma jednoosobowa zalicza się do sektora małych i średnich przedsiębiorstw. W ramach grupy firm małych (a więc zatrudniających włącznie do 49 osób) wyróżnia się kategorię mikroprzedsiębiorstw, zatrudniających do 9 pracowników. Przedsiębiorstwo jednoosobowe z kolei jest podzbiorem w ramach firm mikro.

Gospodarcze znaczenie sektora małych i średnich przedsiębiorstw dostrzec można w świetle dostępnych statystyk. W tabeli $5 \mathrm{w}$ przekrojowy sposób przedstawiono udział poszczególnych grup wielkościowych przedsiębiorstw w Polsce.

Tabela 5. Znaczenie poszczególnych kategorii przedsiębiorstw w Polsce na koniec 2014 roku, w \%

\begin{tabular}{|l|c|c|c|c|}
\hline \multirow{2}{*}{} & \multicolumn{4}{|c|}{ Wielkość podmiotu } \\
\cline { 2 - 5 } & mikro & małe & średnie & duże \\
\hline Liczba przedsiębiorstw & 95,8 & 3,2 & 0,8 & 0,2 \\
\hline Liczba pracujących & 38,2 & 13,4 & 17,6 & 30,8 \\
\hline Przychody ogółem & 20,7 & 14,8 & 19,9 & 44,6 \\
\hline Nakłady inwestycyjne & 16,4 & 10,6 & 19,6 & 53,4 \\
\hline Wartość produkcji & 27,6 & 11,4 & 17,6 & 43,3 \\
\hline
\end{tabular}

Źródło: [GUS 2015].

W powyższym zestawieniu nie występuje kategoria przedsiębiorstwa jednoosobowego, a jedynie mikroprzedsiębiorstwa. Wynika to wprost z praktyki zbierania danych statystycznych przez GUS, który nie uwzględnia w swoich wyliczeniach kategorii firmy jednoosobowej. Z pomocą przychodzą tu jednak dane ZUS, według których na koniec 2014 roku 1,368 miliona osób płaciło składki na ubezpieczenie zdrowotne jedynie za siebie [Stowarzyszenie Samozatrudnieni 2015]. Biorąc pod uwagę, że podmiotów mikro było 1,764 miliona, oznacza to udział firm jednoosobowych w kategorii mikroprzedsiębiorstw oscylujący na poziomie $75 \%$. Tym samym podmioty jednoosobowe odgrywają istotną rolę w wypracowywaniu pozycji ekonomicznej Polski.

$\mathrm{Z}$ epistemologicznego punktu widzenia przedsiębiorstwa jednoosobowe cechują się swoistą specyfiką w przekroju właściwości zarządczych. Specyfikę tę najłatwiej dojrzeć przez porównanie z przedsiębiorstwami o innej skali działalności. W tabeli 6 przedstawiono ustalenia $\mathrm{w}$ tej materii.

Mocne strony przedsiębiorstwa jednoosobowego wiążą się z:

- jednym centrum decyzyjnym,

- brakiem rozdźwięku między zamiarami zarządzającego a realizacją przez wykonawcę, 
Tabela 6. Różnice w zarządzaniu przedsiębiorstwami różnych wielkości

\begin{tabular}{|l|l|l|l|}
\hline \multirow{2}{*}{ Kryterium } & \multicolumn{3}{c|}{ Przedsiębiorstwo } \\
\cline { 2 - 4 } & \multicolumn{1}{|c|}{ jednoosobowe } & \multicolumn{1}{c|}{ małe } & \multicolumn{1}{c|}{ duże } \\
\hline Podejmowanie decyzji & Właściciel & Włáciciel/właściciele & Menedżer/właściciel \\
\hline Podział pracy & Brak & $\begin{array}{l}\text { Pracownicy/ } \\
\text { współwłaściciele }\end{array}$ & $\begin{array}{l}\text { Pracownicy/ } \\
\text { współwłaściciele }\end{array}$ \\
\hline Relacje z klientami & Bliskie & Bliskie & Sformalizowane \\
\hline Procedury wewnętrzne & $\begin{array}{l}\text { Tylko wymuszone } \\
\text { przepisami }\end{array}$ & Niewiele & Wiele \\
\hline Pochodzenie kapitału & Samofinansowanie & Samofinansowanie & Rynek kapitałowy/banki \\
\hline $\begin{array}{l}\text { Korzystanie z usług } \\
\text { zewnętrznych }\end{array}$ & Na szeroką skalę & Na szeroką skalę & Na średnią skalę \\
\hline Struktura organizacyjna & Brak & Prosta & Rozbudowana \\
\hline $\begin{array}{l}\text { Siła przetargowa wobec } \\
\text { dostawców }\end{array}$ & Niewielka & Mała & Duża \\
\hline
\end{tabular}

Źródło: opracowanie własne na podstawie [Daszkiewicz, Wach 2013, s. 22; Poznańska, Schulte-Zurhausen 1994, s. 26].

- wysoką motywacją i zaangażowaniem właściciela/wykonawcy,

- utożsamianiem przedsiębiorstwa z osobą właściciela,

- indywidualnym traktowaniem klientów i kontrahentów,

- nikłą formalizacją.

Z kolei do najważniejszych wad firmy jednoosobowej zaliczyć należy:

- poleganie wyłącznie na jednej osobie (subiektywizm ocen, kompetencje, wolny czas),

- niewielkie zasoby i możliwości skokowego zwiększenia skali działalności,

- koncentracja na działaniu „tu i teraz”,

- uzależnienie od wspomagania się usługami z zewnątrz,

- niską siłę przetargową na rynku.

\section{Zarządzanie zmianą w przedsiębiorstwie jednoosobowym - studium przypadku sklepu internetowego aerografy.com.pl}

Celem postawionym przed artykułem jest jakościowa analiza czynników utrudniających i ułatwiających wdrażanie zmian przez przedsiębiorstwo jednoosobowe, działające w przestrzeni wirtualnej. Aby osadzić analizę w realiach rynkowych, jako podmiot badawczy wybrano funkcjonujący przez wiele lat sklep internetowy.

Metody badawcze przyjęte do zrealizowania obranego celu obejmują krytyczną analizę dokumentacji oraz wywiad skategoryzowany. Studium przypadku zostało 
opracowane na podstawie wywiadu skategoryzowanego przeprowadzonego z właścicielem sklepu aerografy.com.pl w maju 2016 roku.

Sklep internetowy aerografy.com.pl powstał w odpowiedzi na rosnące zainteresowanie technikami malarskimi, do których potrzebne są aerografy. Aerograf to pistolet natryskowy służący do malowania precyzyjnego, np. retuszu, prac konserwatorskich czy modelarskich. Na bazie omawianego urządzenia rozwinęła się aerografia jako technika artystyczna. Rosnący trend wyrażania siebie, pokazania własnej osobowości wygenerował popyt na aerografy. Obecnie w ofercie sklepu znajduje się kilkadziesiąt modeli aerografów. Oprócz tego asortyment sklepu powiększył się o inne przydatne w malowaniu czy modelarstwie towary, takie jak kompresory, przewody ciśnieniowe, farby, szablony, pędzle, kredki, materiały instruktażowe itp. W tym stanie rzeczy oferta sklepu jest komplementarna, niewątpliwie jednak przedmiot sprzedaży ma niszowy charakter.

Przedsiębiorca założył sklep internetowy w 2002 roku na bazie własnego zainteresowania malowaniem. Hobby przekształciło się w działalność profesjonalną. Od momentu startu biznesu przedsiębiorca sam prowadził sklep internetowy. Zajmował się z jednej strony kwestiami strategicznymi dla przetrwania i rozwoju przedsiębiorstwa, takimi jak wybór asortymentu do sprzedaży, jego szerokości i głębokości, wybór platformy sprzedaży. Jednocześnie musiał wykonywać wszystkie czynności fizyczne, związane z przyjęciem, magazynowaniem i wysyłką towaru do klienta, prowadzeniem odpowiedniej dokumentacji itp. Pełnił więc zgodnie z założeniami przedsiębiorstwa jednoosobowego funkcje zarówno regulacyjne, jak i wykonawcze. Ważne jest przy tym, że mógł liczyć na pomoc rodziny w sytuacjach kryzysowych (np. spiętrzenia się terminów).

Mimo nawału zajęć właściciel nie zaniedbywał uważnego śledzenia zmian zachodzących na rynku. W trakcie kilkunastoletniej działalności doszło do wielu zmian o zasadniczym znaczeniu. Przede wszystkim działalność sklepu internetowego uległa dużej profesjonalizacji, zarówno pod kątem merytorycznym, jak i formalnym. Klienci stają się coraz bardziej wymagający, jeżeli chodzi o wybór produktów, cenę i szybkość dostawy oraz kwestię doradztwa. Oferowany towar ma specjalistyczny charakter, co z czasem wymusiło na przedsiębiorcy publikowanie materiałów o poradniczym charakterze. Jednocześnie polski klient - $\mathrm{w}$ opinii indagowanego właściciela - dalej zwraca uwagę przede wszystkim na poziom ceny. Dlatego też przedsiębiorca oprócz doskonalenia aspektów handlowych i marketingowych zwrócił baczną uwagę na kwestię zaopatrzenia. Monitoring rynku wykazał, że konkurenci sprowadzają aerografy z Chin. Import z Dalekiego Wschodu pozwalał na zaoferowania niższych cen, przy powiększeniu marży. Właściciel sklepu zdecydował się nawiązać relację z chińskim producentem, który dostarczał mu aerografy i kompresory pod własną marką.

Drugą zmianą o strategicznym charakterze było uruchomienie stacjonarnego punktu sprzedaży (sklepu fizycznego). Okazało się bowiem, że wielu klientów chciałoby obejrzeć i przetestować towar przed zakupem. Tym samym działalność handlowa przyjęła hybrydową postać - w ramach przedsiębiorstwa pojawiły się dwa kanały 
dystrybucji: wirtualny i tradycyjny. Jednakże cały czas większość przychodów pochodziła z działalności w przestrzeni wirtualnej.

$\mathrm{Z}$ zarządczego punktu widzenia działalność jednoosobowa w omawianym przypadku miała zarówno pozytywny, jak i negatywny wpływ na uwzględnianie zmienności otoczenia. W tabeli 7 wyspecyfikowano czynniki ułatwiające i utrudniające percepcję zmian i ich wdrożenie w życie dla prowadzącego sklep internetowy.

Tabela 7. Czynniki ułatwiające i utrudniające wprowadzanie zmian w sklepie internetowym aerografy.com.pl

\begin{tabular}{|c|c|}
\hline $\begin{array}{l}\text { Czynniki ułatwiające wprowadzanie zmian } \\
\text { w sklepie internetowym }\end{array}$ & $\begin{array}{c}\text { Czynniki utrudniające wprowadzanie zmian } \\
\text { w sklepie internetowym }\end{array}$ \\
\hline $\begin{array}{l}\text { - Zmysł obserwacji zachodzących w Internecie } \\
\text { zmian i rosnące z czasem doświadczenie, które } \\
\text { zmiany są istotne } \\
\text { - Automatyzacja pracy - odpowiednie } \\
\text { ustawienie parametrów oprogramowania } \\
\text { sklepu internetowego, aplikacji } \\
\text { marketingowych itd. pozwala na skupienie się } \\
\text { na meritum biznesu } \\
\text { - Aktualizacja oprogramowania dokonywana } \\
\text { przez firmy informatyczne, korzystanie } \\
\text { z integratorów oprogramowania sprzyja byciu } \\
\text { na bieżąco i bezproblemowemu wdrażaniu } \\
\text { zmian } \\
\text { - Permanentne korzystanie z usług } \\
\text { zewnętrznych (księgowość, marketing, } \\
\text { regulaminy itd.) - otrzymywanie podpowiedzi, } \\
\text { co trzeba w danym momencie zmienić, jak } \\
\text { również wykonywanie konkretnych działań } \\
\text { w imieniu i na rachunek przedsiębiorcy } \\
\text { - Rodzina i znajomi również prowadzą biznes } \\
\text { - co pozwala uczyć się na cudzych błędach } \\
\text { i szybciej dostrzegać szanse }\end{array}$ & $\begin{array}{l}\text { - Przeładowanie informacją (zbyt wiele } \\
\text { bodźców w jednym momencie) } \\
\text { - Ograniczony czas na przefiltrowanie } \\
\text { i przemyślenie znaczenia danej zmiany dla } \\
\text { funkcjonowania e-sklepu } \\
\text { - Braki w zasobach (szczególnie w zakresie } \\
\text { wolnych kapitałów), aby wdrożyć daną } \\
\text { zmianę w życie } \\
\text { - Opór przed powierzeniem części zadań } \\
\text { pracownikom (obawa o poprawne } \\
\text { wykonanie zadania przez osobę } \\
\text { z zewnątrz, obawa przed ujawnieniem } \\
\text { tajemnic firmy) } \\
\text { - Rosnące z czasem przeregulowanie } \\
\text { działalności gospodarczej, co wymusza } \\
\text { konieczność opracowania i przestrzegania } \\
\text { procedur }\end{array}$ \\
\hline
\end{tabular}

Źródło: opracowanie własne.

\section{Zakończenie - implikacje dla praktyki}

Zaprezentowany przykład wskazuje, że obok typowych czynników ułatwiających lub przeszkadzających wprowadzeniu zmiany w firmie jednoosobowej, w jednoosobowym przedsiębiorstwie internetowym pojawiają się dodatkowe elementy.

W pierwszym rzędzie chodzi o ilość informacji cyrkulujących w Internecie (information overload). Oczywiście, nie wszystkie z nich będą miały znaczenie dla danego biznesu, ale nawet i to ograniczenie przekłada się na około 100-200 nowych informacji w skali dnia. A dzieje się to dzień po dniu, w stosunku do jednej osoby. 
Dlatego tak kluczowym rozwiązaniem jest znalezienie takiego oprogramowania, które po odpowiednich dostrojeniach umożliwia bardzo dużą automatyzację działań. W omawianym przypadku chodziło o oprogramowanie sklepu internetowego, które po instalacji i dostrojeniu działało bez bieżącego nadzoru. W tym kontekście występuje też aktualizacja oprogramowania, która dotyczy nie tylko aspektów technologicznych związanych z rozwojem oprogramowania, lecz także uwzględnienia zmian prawnych. Codzienną działalność ułatwiają też integratory pomiędzy poszczególnymi rodzajami stosowanego oprogramowania. W odniesieniu do sklepu aerografy.com.pl integrator umożliwiał hurtowe zarządzanie opisami produktów.

Drugim ważnym trendem jest szerokie korzystanie z usług firm zewnętrznych, wyspecjalizowanych w określonych obszarach. Dla analizowanego przypadku na liście usługodawców zewnętrznych znalazły się: firma hostingowa (utrzymująca dane sklepu na serwerze), dostawca oprogramowania e-sklepu, producent integratora, pozycjoner (usługi marketingowe w wyszukiwarkach), operator płatności poprzez Internet, integrator zlecania przesyłek, graficy przygotowujący oprawę stron WWW, Allegro - jako wiodący serwis aukcyjny w Polsce, agencja interaktywna (zajmująca się reklamą on line), twórcy zgodnych z prawem regulaminów sklepów internetowych. Oprócz tego przedsiębiorca korzystał także z usług księgowych i prawniczych. Tak więc zakres i zasięg działalności zewnętrznej pozwalał skupić się na core business $\mathrm{z}$ jednej strony, a $\mathrm{z}$ drugiej umożliwił funkcjonowanie bez pojawienia się $\mathrm{w}$ firmie chociażby jednego pracownika. To też jest symptomatyczny objaw - brak nacisku na zatrudnianie kogokolwiek z zewnątrz. Natomiast w to miejsce pojawia się - i jest przyjmowana - pomoc nieformalna ze strony rodziny czy znajomych.

Na koniec warto przytoczyć jedno ze spostrzeżeń indagowanego przedsiębiorcy. Stwierdził on mianowicie, że w ciągu 14 lat prowadzenia działalności lawinowo narasta liczba uregulowań prawnych, co w znaczący sposób usztywnia zarządzanie nawet tak małym podmiotem gospodarczym.

\section{Literatura}

Allen R., 2016, What happens online in 60 seconds?, http://www.smartinsights.com/internet-marketing-statistics/happens-online-60-seconds/.

Amit R., Zott Ch., 2001, Value creation in E-business, Strategic Management Journal, vol. 22, iss. 6-7, s. 493-520.

Clarke L., 1997, Zarzadzanie zmiana, Gebethner i Ska, Warszawa.

Daszkiewicz N., Wach K., 2013, Mate i średnie przedsiębiorstwa na rynkach międzynarodowych, Wyd. Uniwersytetu Ekonomicznego w Krakowie, Kraków.

Gruszecki T., 2002, Wspótczesne teorie przedsiębiorstwa, PWN, Warszawa.

GUS, 2015, Działalność przedsiębiorstw niefinansowych w 2014 r., http://stat.gov.pl/download/gfx/ portalinformacyjny/pl/defaultaktualnosci/5502/2/11/1/pgwf_dzialalnosc_przedsiebiorstw_niefinansowych_w_2014.pdf.

Hayes J., 2014, The Theory and Practice of Change Management, Palgrave Macmillan, New York.

IDG S.A., 2010, Internet 2k10, http://files.idg.pl/news/Raport_Internet_2k10.zip. 
Karaś M., 2003, Przedsiębiorstwo, [w:] Podstawy nauki o przedsiębiorstwie, red. J. Lichtarski, Wydawnictwo Akademii Ekonomicznej we Wrocławiu, Wrocław.

Kotler Ph., Caslione J.A., 2009, Chaos. Zarzadzanie i marketing w erze turbulencji, MT Biznes, Warszawa.

Moroz M., 2013, Ksztaltowanie elastyczności przedsiębiorstw internetowych, Wydawnictwo Uniwersytetu Ekonomicznego we Wrocławiu, Wrocław.

Poznańska K., Schulte-Zurhausen M., 1994, Kryteria klasyfikacji małych i średnich przedsiębiorstw, Przegląd Organizacji, nr 2, s. 26-27.

Stowarzyszenie Samozatrudnieni, 2015, Nikt nie wie ile jest $w$ Polsce samozatrudnionych i freelancerów, http://samozatrudnieni.org/badania/nikt-nie-wie-ilu-jest-w-polsce-samozatrudnionych-ifreelancerow/.

Ścibior M., 2008, Polski e-commerce na zakręcie?, http://www.internetstandard.pl/news/169511/Polski.e.commerce.na.zakrecie.html. 